\title{
Effects of different cultivated regions on bioactive compound content and antioxidant activity of aronia (Aronia melanocarpa)
}

\author{
Eun-Sun Hwang*, You Ji Lee \\ School of Wellness Industry Convergence, Major in Food and Nutrition, \\ Hankyong National University, Anseong 17579, Korea
}

\begin{abstract}
This study aimed to compare the bioactive substances and antioxidant activities of aronia grown in Korea and Poland, and thus to provide basic data for its future use as a processed food. The powders of three types of aronia, each from Korea and Poland, were extracted with distilled water and $80 \%$ ethanol at $25^{\circ} \mathrm{C}$ and $80^{\circ} \mathrm{C}$, respectively, and the total polyphenol, flavonoid, and anthocyanin contents were evaluated. Additionally, the antioxidant activities were compared with DPPH and ABTS radical scavenging activities and reducing power depending on the extraction temperature and extraction solvent. The total polyphenol content was higher in the $80 \%$ ethanol extracts than the water extracts, in the six samples from Korea and Poland. The total polyphenols and flavonoids were higher in water extracts at $80^{\circ} \mathrm{C}$ than at $25^{\circ} \mathrm{C}$, and at $80^{\circ} \mathrm{C}$ in $80 \%$ ethanol. The anthocyanin content in the other five samples showed a similar tendency except for sample $E$, which had the highest anthocyanin content, based on $80 \%$ ethanol extract. The $80 \%$ ethanol extract showed higher antioxidant activity than water extract and in the aronia water extract, the antioxidant activity of the sample extracted at $80^{\circ} \mathrm{C}$ was higher than that of the $25^{\circ} \mathrm{C}$ extract at the same concentration. Based on these findings, it was confirmed that the antioxidative activity of Korea aronia was either similar to that of the Polish variant or was slightly higher.
\end{abstract}

Key words : aronia, Korea, Poland, anthocyanins, antioxidant activity

\section{Introduction}

Aronia (Aronia melanocarpa) is a deciduous shrub belonging to the Rosaceae family, which grows in the northeastern part of North America, and is also known as the black chokeberry (Tolic et al., 2015; Wu et al., 2004). Recently, aronia has been cultivated in eastern European countries, Russia and Korea, and its cultivation and yield are gradually increasing (Domarew et al., 2002; Hwang and Thi, 2016). Aronia is known to have a higher content of polyphenols, phenolic acids, proanthocyanidins, anthocyanins, flavonols and flavanones than the other berries (Koponen et al., 2007; Slimestad et al., 2005; Wu et al., 2004). Aronia is known to have excellent in antioxidant activity, and is highly effective in preventing arteriosclerosis, cardiovascular disease, cancer and diabetes (Girones-Vilaplana et al., 2012; Hellstrom et al., 2010; Jakobek et al., 2012). Like other general fruits and vegetables, aronia may have different physiologically active substances, or exhibit antioxidant activity based on the cultivation environment such as temperature, rainfall, and sunshine in the cultivation area or during the cultivation period (Jeong et al., 2016; Tolic et al., 2015).

As aronia cannot be harvested all year long and has a strong sour and astringent taste as compared to other berries, research is being conducted to add it to various processed

\footnotetext{
*Corresponding author. E-mail : ehwang@hknu.ac.kr, Phone : +82-31-670-5182, Fax : +82-31-670-5189

Received 29 April 2020; Revised 17 June 2020; Accepted 29 June 2020.

Copyright (c) The Korean Society of Food Preservation.

This is an Open Access article distributed under the terms of the Creative Commons Attribution Non-Commercial License (http://creativecommons.org/licenses/by-nc/4.0) which permits unrestricted non-commercial use, distribution, and reproduction in any medium, provided the original work is properly cited.
} 
foods in the form of lyophilized powder or extract, instead of eating raw fruits (Hwang and Thi, 2014). Aronia cultivation is increasing, and research shows that ingestion of aronia is beneficial to health, adding aronia to various foods such as juice, yogurt, rice cakes, and cookies (Hwang and Hwang, 2015; Lee and Choi, 2016; Nguyen and Hwang, 2016). Although the development and demand for processed products containing aronia is increasing, few studies have been conducted to compare the antioxidant contents of aronia growing regions. In addition, consumer interest in physiological activity and antioxidant efficacy in aronia cultivation area is increasing. At point where Korea cultivation of aronia is rapidly increasing, we wanted to compare bioactive contents and antioxidant activities of Korea and Polish aronia, which accounts for more than $80 \%$ of the global market. In this study, we compared the contents of bioactive substances and antioxidant activities of three aronia plants cultivated in three different regions of Korea, and three aronia powders imported from Poland. These results were intended to be used as basic data for making functional products by adding aronia, in the future.

\section{Materials and methods}

\section{Chemicals}

Folin-Ciocalteu's phenol reagent, catechin, gallic acid, 2,2-diphenyl-1-picrylhydrazyl (DPPH) radical, Tris-HCl, 2,2'-azino-bis-3-ethylbenzothiazoline-6-sulfonic acid (ABTS), nicotinamide adenine dinucleotide (NADH), and $p$-methyl styrene (PMS) were purchased from Sigma Chemicals (St. Louis, MO, USA). Anthocyanin and polyphenol standards for high performance liquid chromatography analysis were purchased from Extrasynthese (Genay, France) and Sigma Chemicals, respectively. HPLC grade water, methanol, acetonitrile, and trifluoroacetic acid (TFA) were purchased from Fisher Scientific Inc. (Fair Lawn, NJ, USA). All chemicals used were of analytical grade.

\section{Sample preparation}

Three sets of freeze-dried powder made from whole aronia (A. melanocarpa), with the skin and seeds of the Nero varieties harvested in 2017 in Korea and Poland, were purchased from a local market. Each freeze-dried powder was extracted with 25 times volume of water or $80 \%$ ethanol. Water extraction was performed at 25 and $80^{\circ} \mathrm{C}$, and $80 \%$ ethanol extraction was performed at 25 and $80^{\circ} \mathrm{C}$ for $2 \mathrm{~h}$ to compare antioxidants and antioxidant effects according to extraction solvent and extraction temperature. Then, the samples were extracted by filtering the mixture through a Whatman \#2 filter paper (Whatman International Ltd., Maidstone, UK) with a vacuum filter; this process was repeated three times. The extracted filtrate was then evaporated using a rotary evaporator (EYELA, Tokyo, Japan) under reduced pressure, at $40^{\circ} \mathrm{C}$. The extracts were freeze-dried in a freeze-drier (Ilshin, Seoul, Korea), finely ground with a cooled mortar and pestle to a particle size < $1.0 \mathrm{~mm}$, and kept in air-tight plastic bags at $-20^{\circ} \mathrm{C}$ until analysis.

\section{Determination of total polyphenols and total flavonoids}

For determination of total polyphenol content, the FolinCiocalteu's phenol reagent was used (Waterhouse, 2002). Briefly, $200 \mu \mathrm{L}$ of the appropriately diluted sample was mixed with $400 \mu \mathrm{L}$ of $2 \% 2 \mathrm{~N}$-Folin-Ciocalteu's phenol reagent. After $3 \mathrm{~min}$ at room temperature (RT), $800 \mu \mathrm{L}$ of $10 \% \mathrm{Na}_{2} \mathrm{CO}_{3}$ was added and mixed. Next, the mixture was kept in the dark by covering with aluminum foil at RT for $1 \mathrm{~h}$. After vortexing, the absorbance was measured at 750 nm using a microplate reader (Infinite M200 Pro, Tecan Group Ltd., San Jose, CA, USA). Gallic acid was used as a calibration standard, and the results were expressed as gallic acid equivalents (GAE) per gram dry weight (mg $\mathrm{GAE} / \mathrm{g}$ ).

The total flavonoid content of the ethanolic extract of aronia was measured using the method described by Woisky and Salatino (1998) with slight modifications. Briefly, 500 $\mu \mathrm{L}$ of the sample was mixed with $30 \mu \mathrm{L} 5 \% \mathrm{NaNO}_{2}$ and allowed to react for $6 \mathrm{~min}$ at RT. Next, $60 \mu \mathrm{L} \mathrm{10 \%} \mathrm{AlCl}_{3}$. $6 \mathrm{H}_{2} \mathrm{O}$ was added, and the mixture was continuously mixed at RT for 6 min followed by the addition of $200 \mu \mathrm{L}$ of 1.0 $\mathrm{M} \mathrm{NaOH}$. Finally, $110 \mu \mathrm{L}$ distilled water was added and mixed. The absorbance of the colored flavonoid-aluminum complex was measured immediately at $510 \mathrm{~nm}$ using a microplate reader. Catechin was used as a calibration standard, and the results were expressed as catechin equivalents (CE) per gram dry weight (mg $\mathrm{CE} / \mathrm{g}$ ). 


\section{Extraction and quantification of anthocyanins and polyphenols by HPLC}

Powdered samples $(100 \mathrm{mg})$ were weighed; $5 \mathrm{~mL}$ methanol containing $0.1 \%$ formic acid was added to the mixture, followed by vortex mixing for $1 \mathrm{~min}$. The mixture was centrifuged for $5 \mathrm{~min}$, and the top layer was transferred to another glass tube. The aqueous layer was extracted with another $5 \mathrm{~mL}$ of methanol containing $0.1 \%$ formic acid. The extraction was performed 3-4 times until aronia extracts were colorless. The methanolic fractions were combined and evaporated to dryness in a rotary evaporator (EYELA, Tokyo, Japan). The residue was dissolved again in extraction solvent obtaining an appropriate concentration for HPLC analysis, and a $10 \mu \mathrm{L}$ volume was injected. The anthocyanins were separated using a $\mathrm{C}_{18}$ Zorbox SB column $(4.6 \times 250 \mathrm{~mm}, 5 \mathrm{~mm}$ particle size, Agilent Technologies Inc., Santa Clara, CA, USA).

The solvent system employed was (A) water with 5\% formic acid and (B) acetonitrile with 5\% formic acid. The samples were separated according to the following gradient: $\mathrm{A} / \mathrm{B}=95 / 5$ (0-5 $\mathrm{min}), 90 / 10$ (8 $\mathrm{min}), 85 / 15$ (13-18 $\mathrm{min})$, $80 / 20$ (25 min), 70/30 (28-32 $\mathrm{min}), 95 / 5$ (35-40 $\mathrm{min})$ at a flow rate of $0.8 \mathrm{~mL} / \mathrm{min}$. The peaks were detected using a UV detector at $520 \mathrm{~nm}$ (Waters Co., Milford, MA, USA).

\section{DPPH radical scavenging assay}

The DPPH radical scavenging activity of $80 \%$ ethanolic extract of aronia was determined using the method described by Cheung et al. (2003), with slight modifications. First, 192 $\mu \mathrm{L}$ solution of $50 \mu \mathrm{M}$ DPPH was mixed with $48 \mu \mathrm{L}$ diluted sample in a $4: 1(\mathrm{v} / \mathrm{v})$ ratio. After leaving the mixture in the dark, covered with aluminum foil at room temperature for $30 \mathrm{~min}$, a control consisting of $48 \mu \mathrm{L}$ distilled water in 192 $\mu \mathrm{L}$ of $50 \mu \mathrm{M}$ DPPH, or $48 \mu \mathrm{L}$ of $94 \%$ ethanol in $192 \mu \mathrm{L}$ of $50 \mu \mathrm{M}$ DPPH was used for the samples. The decolorization of DPPH was read at $517 \mathrm{~nm}$ using a microplate reader. The DPPH radical scavenging activity was calculated according to the following equation:

$$
\text { Inhibition }(\%)=\left[\left(\mathrm{A}_{\text {control }}-\mathrm{A}_{\text {sample }}\right) / \mathrm{A}_{\text {control }}\right] \times 100
$$

Where, $\mathrm{A}_{\text {control }}$ is the absorbance of the control reaction (containing all reagents except for the test compound) and $\mathrm{A}_{\text {sample }}$ is the absorbance of the test compound.

\section{$A B T S$ radical scavenging assay}

The ABTS radical scavenging activity of aronia extract was determined using the method described by $\mathrm{Re}$ et al. (1999), with slight modifications. First, ABTS was dissolved in distilled water to obtain a $7 \mathrm{mM}$ concentration. The ABTS radical cation was produced by reacting the ABTS stock solution with $2.45 \mathrm{mM} \mathrm{K} \mathrm{S}_{2} \mathrm{O}_{8}$ (at a ratio of 2:1) in the dark, covered with aluminum foil for $24 \mathrm{~h}$ before use. The ABTS reagent was diluted with $94 \%$ ethanol to obtain an appropriate absorbance $(0.17 \pm 0.03)$, which was measured at $734 \mathrm{~nm}$. Then, $950 \mu \mathrm{L}$ of the ABTS reagent was mixed with $50 \mu \mathrm{L}$ of several concentrations of the tested samples. After leaving the mixture in the dark, covered with aluminum foil at room temperature for $10 \mathrm{~min}$, the absorbance at $734 \mathrm{~nm}$ was measured using a microplate reader. Each sample was measured in triplicate, and the percentage (\%) inhibition was calculated using the following equation:

$$
\text { Inhibition }(\%)=\left[\left(\mathrm{A}_{\text {control }}-\mathrm{A}_{\text {sample }}\right) / \mathrm{A}_{\text {control }}\right] \times 100
$$

Where, $\mathrm{A}_{\text {control }}$ is the absorbance of the control reaction (containing all reagents except for the test compound) and $\mathrm{A}_{\text {sample }}$ is the absorbance of the test compound.

\section{Reducing power activity}

The $\mathrm{Fe}^{3+}$ reducing power of the extracts was determined using the method of Oyaizu (1986) with slight modification. Various concentrations of the samples $(0.25 \mathrm{~mL})$ were mixed with $0.25 \mathrm{~mL}$ of phosphate buffer $(0.2 \mathrm{M}, \mathrm{pH} 6.6)$ and $0.25 \mathrm{~mL}$ of potassium hexacyanoferrate (III) $\left[\mathrm{K}_{3} \mathrm{Fe}(\mathrm{CN})_{6}\right.$, $1 \%(\mathrm{w} / \mathrm{v})]$. The mixture was incubated at $50^{\circ} \mathrm{C}$ in water bath for $20 \mathrm{~min}$, and the reaction was stopped by adding 0.25 $\mathrm{mL}$ of trichloroacetic acid (TCA) solution $(10 \%, \mathrm{w} / \mathrm{v})$; the mixture was centrifuged at $3,000 \mathrm{rpm}$ for $10 \mathrm{~min}$. The supernatant $(0.5 \mathrm{~mL})$ was mixed with $0.5 \mathrm{~mL}$ of distilled water and $0.1 \mathrm{~mL}$ of ferric chloride $\left(\mathrm{FeCl}_{3}\right)$ solution $(0.1 \%$, $\mathrm{w} / \mathrm{v}$ ) for $10 \mathrm{~min}$. The reducing power was determined by measuring the absorbance at $700 \mathrm{~nm}$ with a microplate reader (Infinite M200 Pro, Tecan Group Ltd., San Jose, CA, USA).

\section{Statistical analysis}

All the results are presented as means \pm SD. Statistical 
analyses were performed using the statistical analysis system, Statistical Package for the Social Sciences (SPSS Inc., Chicago, IL, USA). Data were compared using one-way analysis of variance; $p<0.05$ was considered significant.

\section{Results and discussion}

\section{Total polyphenol contents}

The total phenolic contents of aronia grown in different countries are presented in Fig. 1. In all six samples, the total polyphenol content was higher in the $80 \%$ ethanol extract than in the water extract, and the optimum extraction temperature varied, depending on the extraction solvent. In case of water extraction, the total polyphenol content of the sample extracted at $80^{\circ} \mathrm{C}$ was higher than that of the sample extracted at $25^{\circ} \mathrm{C}$. In the water extract extracted at $25^{\circ} \mathrm{C}$, the Korean aronia showed a total polyphenol content of 22.95-44.16 mg GAE/g dry weight, while Polish aronia showed a polyphenol content of 37.97-51.53 mg GAE/g dry weight, under the same conditions. In the water extract extracted at $80^{\circ} \mathrm{C}$, Korean aronia showed a total polyphenol content of 108.13-121.61 mg GAE/g dry weight, and Polish aronia had a polyphenol content of 85.23-101.25 mg GAE/g dry weight under the same conditions. In the $80 \%$ ethanol extracted at $25^{\circ} \mathrm{C}$, Korean aronia showed a total polyphenol content of $165.13-173.54 \mathrm{mg}$ GAE/g dry weight, while Polish aronia showed a polyphenol content of 145.23-158.31 mg GAE/g dry weight, under the same conditions. In $80 \%$ ethanol extracted at $80^{\circ} \mathrm{C}$, the Korean aronia showed a total

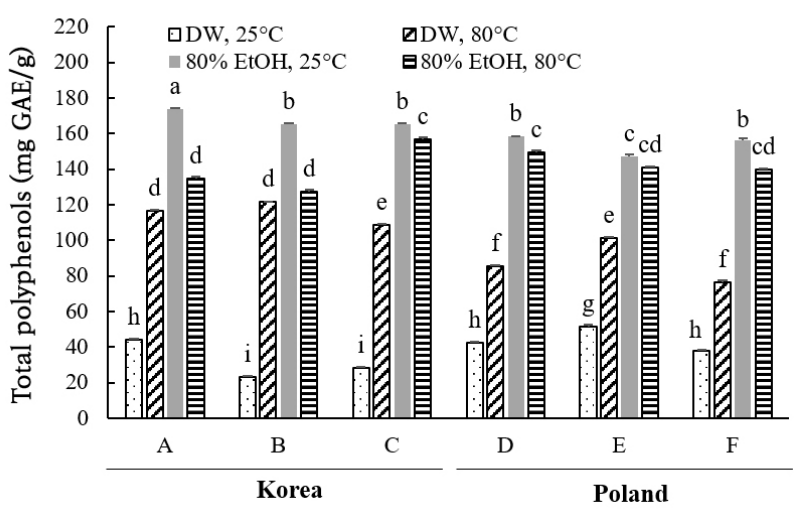

Fig. 1. The total polyphenol contents of aronia in different cultivated regions.

${ }^{a-i}$ Different letters above the bars are significantly different by Duncan's multiple range test at $\mathrm{p}<0.05$. polyphenol content of 127.45-156.81 mg GAE/g dry weight, while Polish aronia showed a polyphenol content of 139.66-149.38 mg GAE/g dry weight, under the same conditions.

These results show that the Korean aronia has a total polyphenol content similar to that of Poland aronia. The difference in total polyphenol content is believed to depend on the extraction solvent or extraction temperature rather than the aronia growing region. Aronia is composed of various polyphenolic compounds such as phenolic acid and quercetin derivatives (Oszmianski and Wojdylo, 2005), and in particular, polyphenols are known to be associated with antioxidant activity (Bolling et al., 2015). The polyphenolic compounds contained in aronia differ based on the variety, origin, plantation, harvest time, etc., and the content is considered to be different depending on the pretreatment process such as extraction solvent, time and method of the lyophilized powder sample (Jeon et al., 2018; Takashi, 1983).

\section{Total flavonoid contents}

The total flavonoid contents of aronia grown in different countries are presented in Fig. 2. By measuring the total flavonoid content of the six samples, the total flavonoid content was found to be higher in the $80 \%$ ethanol extract than in the water extract. The total flavonoid content according to the extraction solvent and extraction temperature was higher in order of $25^{\circ} \mathrm{C}$, distilled water $<80^{\circ} \mathrm{C}$, distilled water $<80^{\circ} \mathrm{C}, 80 \%$ ethanol $<25^{\circ} \mathrm{C}, 80 \%$ ethanol extract. The

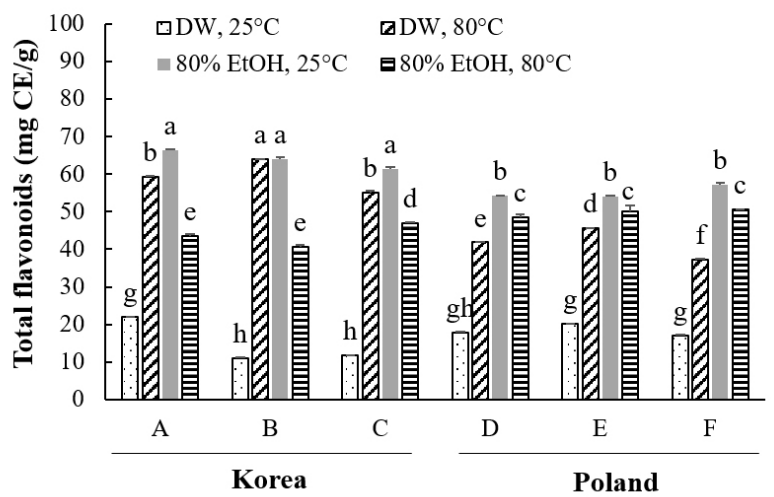

Fig. 2. The total flavonoid contents of aronia in different cultivated regions.

${ }^{\text {a-h }}$ Different letters above the bars are significantly different by Duncan's multiple range test at $\mathrm{p}<0.05$. 
total polyphenol content of aronia water extract was 10.91-22.02 mg CE/g dry weight of Korean aronia when extracted at $25^{\circ} \mathrm{C}$ and $16.93-20.11 \mathrm{mg} \mathrm{CE} / \mathrm{g}$ dry weight of aronia from Poland. The water extracted at $80^{\circ} \mathrm{C}$ showed 55.06-63.91 mg CE/g dry weight of total flavonoid content per gram of Korean aronia and flavonoids of 37.19-45.65 $\mathrm{mg} \mathrm{CE} / \mathrm{g}$ dry weight, under the same conditions. In $80 \%$ ethanol extracted at $25^{\circ} \mathrm{C}$, Korean aronia showed a total flavonoid content of 61.37-66.35 mg CE/g dry weight, while Polish aronia showed a total flavonoid content of 54.05$57.28 \mathrm{mg} \mathrm{CE} / \mathrm{g}$ dry weight, under the same conditions. In the $80 \%$ ethanol extracted at $80^{\circ} \mathrm{C}$, Korean aronia showed a total flavonoid content of 40.67-46.98 mg CE/g dry weight, while Polish aronia showed a polyphenol content of 48.57-50.50 mg CE/g dry weight, under the same conditions. The results showed that Korean aronia has total flavonoid content similar to that of Polish aronia.

\section{Extraction and quantification of anthocyanins}

Fig. 3 shows a chromatogram to analyze anthocyanins in freeze-dried aronia powder, obtained by injection into HPLC after extraction with water and $80 \%$ ethanol. HPLC analysis
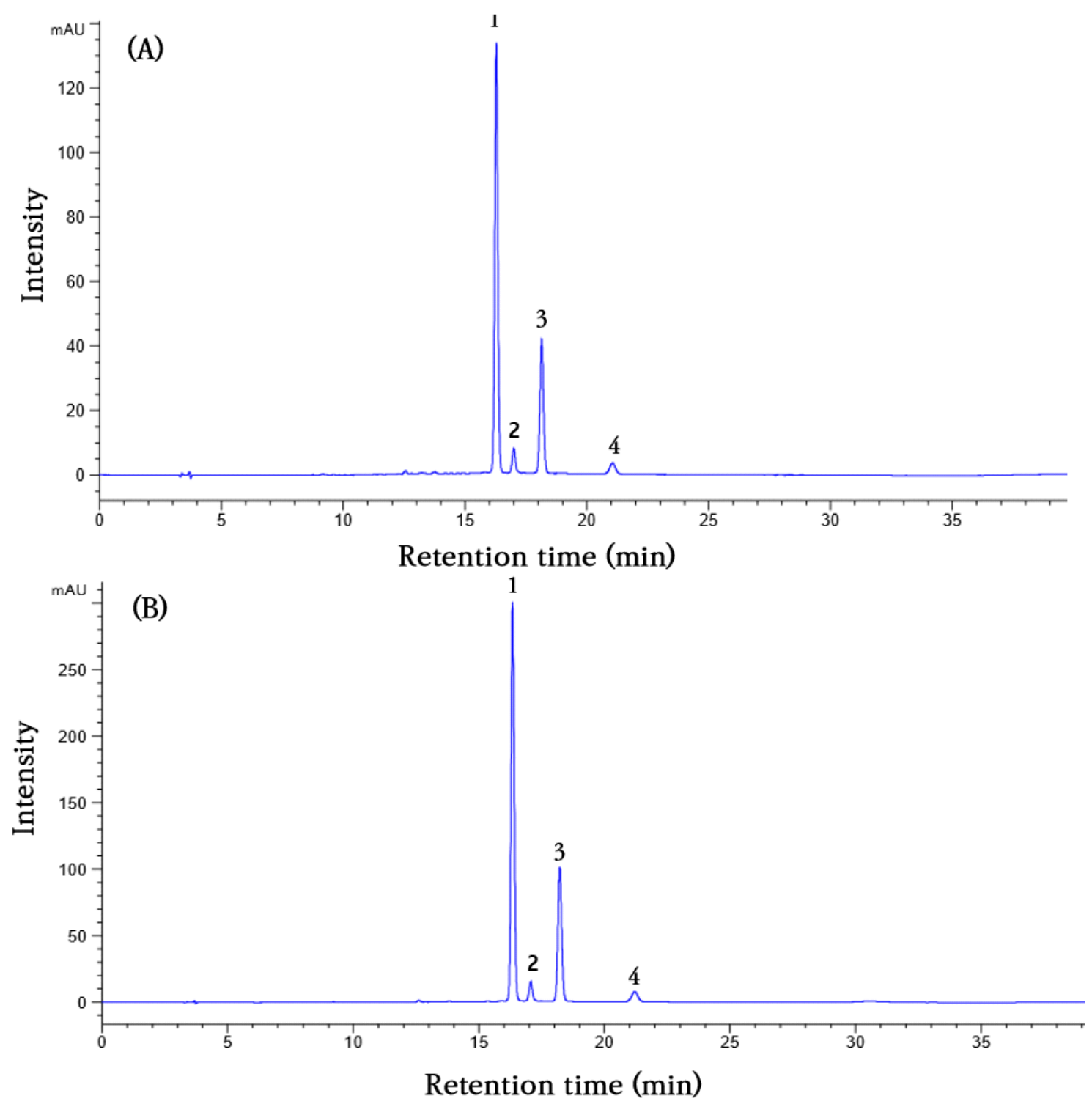

Fig. 3. High-performance liquid chromatography (HPLC) chromatograms of anthocyanins isolated in aronia from (A) water extract and (B) 80\% ethanol extract: (1) cyanidin-3-O-galactoside, (2) cyanidin-3-O-glucoside, (3) cyanidin-3-O-arabinoside, and (4) cyanidin-3- $O$-xyloside. 
identified four anthocyanin substances of cyanidin-3-Ogalactoside, cyanidin-3-O-glucoside, cyanidin-3-O-arabinose, and cyanidin-3-O-xylose, and their retention times were $16.4,17.1,18.2$, and $21.3 \mathrm{~min}$, respectively. Cyanidin-3-Ogalactoside was the major anthocyanin followed by cyanidin3-O-arabinoside, cyanidin-3-O-glucoside, and cyanidin-3$O$-xylose.

Fig. 4 shows the results of anthocyanin content analysis using HPLC, from aronia water or $80 \%$ ethanol extract. Extraction at $25^{\circ} \mathrm{C}$ in 4 different anthocyanin compounds, water and $80 \%$ ethanol extract showed higher anthocyanin content than that extracted at $80^{\circ} \mathrm{C}$. Overall, the anthocyanin content of sample E, which was from Poland, was the highest, and the anthocyanin content of sample $\mathrm{B}$, which was Korean, was low. In case of cyanidin-3-O-galactoside, the highest content of $\mathrm{E}(14,869.98 \mathrm{mg})$ among the six samples, A (9,217.16 mg) and C (8,043.24 mg). Sample E showed about 2.3 times higher cyanidin-3- $O$-galactoside than sample B. In cyanidin-3-O-glucoside, sample E showed highest content of cyanidin-3-O-glucoside, which was 706.39 $\mathrm{mg}$, among the six samples, and followed by A $(441.93 \mathrm{mg})$, F (416.50 mg), D (412.52 mg), C (402.92 mg), and B (393.24 mg). The anthocyanin content in the other five samples showed a similar tendency except for sample E, which had the highest anthocyanin content, in the $80 \%$ ethanol extract.

Anthocyanins are high in purple fruits and vegetables, especially berries, including aronia. Anthocyanins contained in aronia exist in the form of glycosides combined with cyanidin, and in aronia, four anthocyanins such as cyanidin-3-O-galactoside, cyanidin-3-O-glucoside, cyanidin3-O-arabinoside, and cyanidin-3-O-xyloside are found. This is similar to the results of previous researches (Hwang and Thi, 2018; Jakobek et al., 2012; Slimestad et al., 2012). The content of anthocyanin in aronia is thought to be influenced by the country of origin, variety, soil environment and timing (Jeon et al., 2018). Anthocyanins in fruits are reported to promote biosynthesis due to the effects of mineral quality,

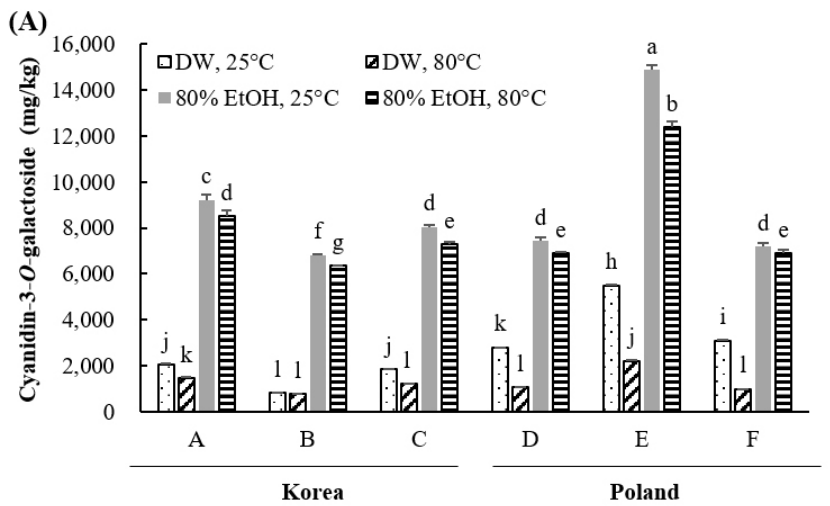

(C)

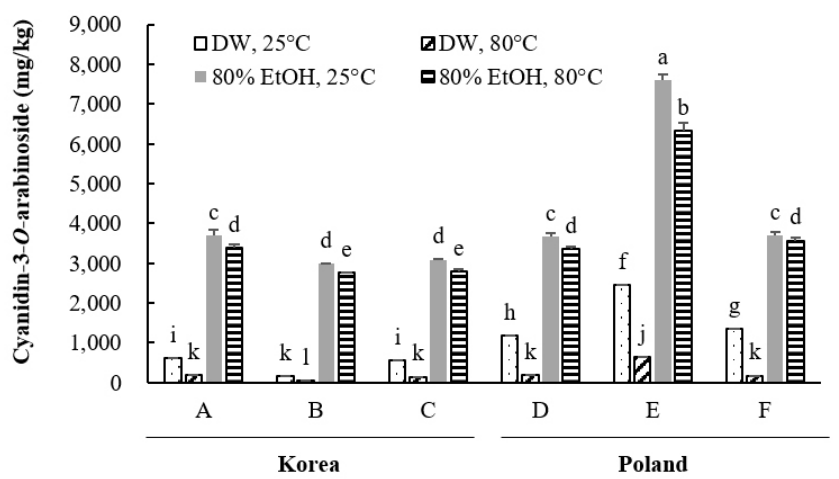

(B)

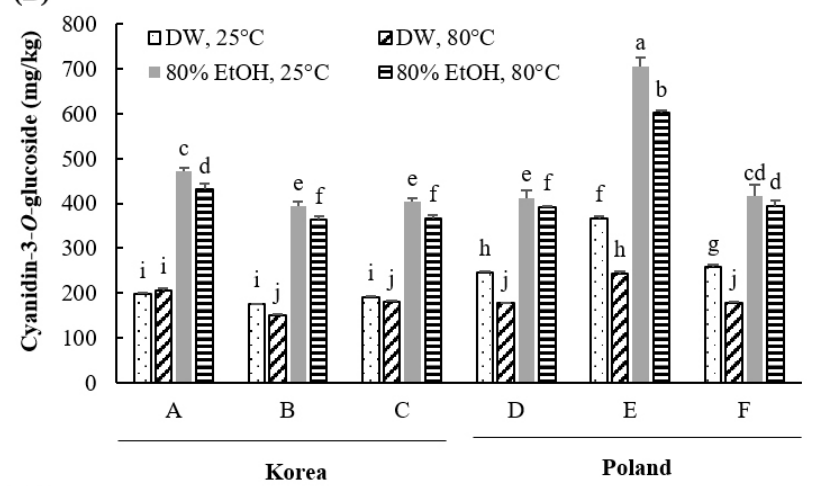

(D)

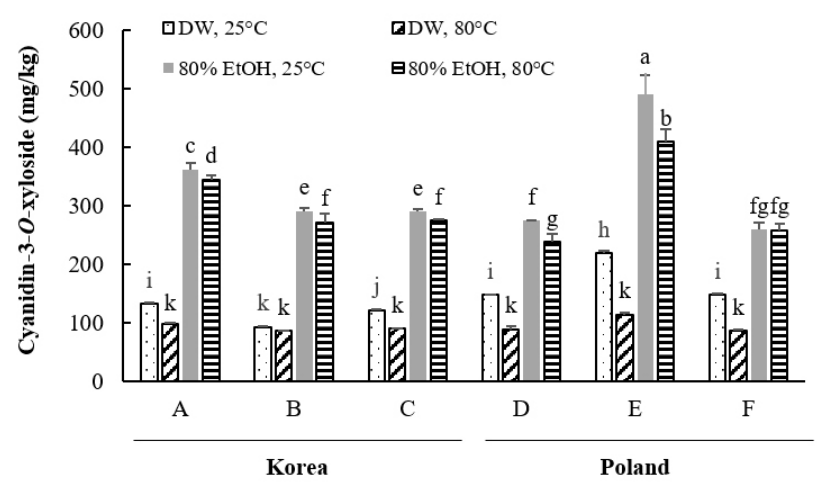

Fig. 4. The individual anthocyanin contents of aronia in different cultivated regions.

(A), cyanidin-3-O-galactoside; (B), cyanidin-3- $O$-glucoside; (C), cyanidin-3- $O$-arabinoside; (D), cyanidin-3- $O$-xyloside.

${ }^{\mathrm{a}-\mathrm{l}}$ Different letters above the bars are significantly different by Duncan's multiple range test at $\mathrm{p}<0.05$. 
Table 1. DPPH radical scavenging activity of aronia in different cultivated regions

\begin{tabular}{|c|c|c|c|c|c|c|c|c|c|}
\hline \multirow{3}{*}{\multicolumn{2}{|c|}{$\begin{array}{c}\text { Cultivated } \\
\text { regions }\end{array}$}} & \multicolumn{8}{|c|}{ Concentration $(\mu \mathrm{g} / \mathrm{mL})$} \\
\hline & & \multicolumn{2}{|l|}{50} & \multicolumn{2}{|c|}{100} & \multicolumn{2}{|c|}{200} & \multicolumn{2}{|c|}{400} \\
\hline & & $\mathrm{LT}^{1)}$ & HT & $\mathrm{LT}$ & HT & $\mathrm{LT}$ & HT & $\mathrm{LT}$ & HT \\
\hline \multicolumn{10}{|c|}{ DW extract } \\
\hline \multirow[t]{3}{*}{ Korea } & A & $9.25 \pm 0.37^{2)(3) A 4)}$ & $28.05 \pm 0.35^{\mathrm{eC}}$ & $17.55 \pm 0.76^{\mathrm{eB}}$ & $45.38 \pm 0.40^{\mathrm{bE}}$ & $30.87 \pm 0.34^{\mathrm{eD}}$ & $63.58 \pm 0.43^{\mathrm{eG}}$ & $48.90 \pm 0.48^{\mathrm{eF}}$ & $72.01 \pm 0.17^{\mathrm{bcH}}$ \\
\hline & B & $8.54 \pm 0.54^{\mathrm{cA}}$ & $25.12 \pm 1.01^{\mathrm{cC}}$ & $16.52 \pm 1.46^{\mathrm{dB}}$ & $49.30 \pm 0.28^{\mathrm{dE}}$ & $27.85 \pm 1.06^{\mathrm{cC}}$ & $65.26 \pm 0.12^{\mathrm{fF}}$ & $45.01 \pm 0.89^{\mathrm{cD}}$ & $71.62 \pm 0.39^{\mathrm{bG}}$ \\
\hline & $\mathrm{C}$ & $6.21 \pm 0.95^{\mathrm{bA}}$ & $24.84 \pm 2.75^{\mathrm{bC}}$ & $12.89 \pm 0.86^{\mathrm{bB}}$ & $46.18 \pm 1.05^{\mathrm{bE}}$ & $25.04 \pm 1.43^{\mathrm{bC}}$ & $61.99 \pm 1.07^{\mathrm{cF}}$ & $41.85 \pm 1.20^{\mathrm{bD}}$ & $71.12 \pm 0.46^{\mathrm{bG}}$ \\
\hline \multirow[t]{3}{*}{ Poland } & $\mathrm{D}$ & $7.43 \pm 1.01^{\mathrm{bA}}$ & $25.07 \pm 1.14^{\mathrm{cC}}$ & $13.22 \pm 2.78^{\mathrm{bB}}$ & $49.32 \pm 3.30^{\mathrm{dE}}$ & $26.70 \pm 0.61^{\mathrm{cC}}$ & $60.90 \pm 2.24^{\mathrm{bF}}$ & $41.80 \pm 0.35^{\mathrm{bD}}$ & $72.81 \pm 0.89^{\mathrm{cG}}$ \\
\hline & $\mathrm{E}$ & $8.79 \pm 0.51^{\mathrm{cA}}$ & $26.18 \pm 2.23^{\mathrm{dC}}$ & $15.85 \pm 1.34^{\mathrm{cB}}$ & $47.49 \pm 4.58^{\mathrm{cE}}$ & $28.35 \pm 0.68^{\mathrm{dD}}$ & $62.65 \pm 7.16^{\mathrm{dF}}$ & $46.94 \pm 0.30^{\mathrm{dE}}$ & $71.35 \pm 2.29^{\mathrm{bG}}$ \\
\hline & $\mathrm{F}$ & $5.86 \pm 0.33^{\mathrm{aA}}$ & $20.57 \pm 3.60^{\mathrm{aC}}$ & $11.87 \pm 0.88^{\mathrm{aB}}$ & $41.15 \pm 5.42^{\mathrm{aF}}$ & $23.42 \pm 0.68^{\mathrm{aD}}$ & $59.91 \pm 4.00^{\mathrm{aG}}$ & $39.30 \pm 0.47^{\mathrm{aE}}$ & $70.12 \pm 0.98^{\mathrm{aH}}$ \\
\hline \multicolumn{10}{|c|}{$80 \% \mathrm{EtOH}$ extract } \\
\hline \multirow[t]{3}{*}{ Korea } & A & $13.45 \pm 0.70^{\mathrm{aA}}$ & $32.65 \pm 1.05^{\mathrm{bB}}$ & $37.79 \pm 0.61^{\mathrm{dC}}$ & $56.82 \pm 0.47^{\mathrm{cE}}$ & $50.79 \pm 0.54^{\mathrm{cD}}$ & $69.55 \pm 0.41^{\mathrm{abG}}$ & $68.57 \pm 0.58^{\mathrm{cF}}$ & $73.05 \pm 0.24^{\mathrm{cH}}$ \\
\hline & B & $15.93 \pm 0.98^{\mathrm{bA}}$ & $39.94 \pm 1.41^{\mathrm{dC}}$ & $37.95 \pm 0.24^{\mathrm{dB}}$ & $58.64 \pm 0.60^{\mathrm{dE}}$ & $51.94 \pm 0.17^{\mathrm{dD}}$ & $70.13 \pm 0.46^{\mathrm{bF}}$ & $69.52 \pm 0.32^{\mathrm{dF}}$ & $74.21 \pm 0.63^{\mathrm{dG}}$ \\
\hline & $\mathrm{C}$ & $17.50 \pm 0.91^{\mathrm{cA}}$ & $32.71 \pm 1.07^{\mathrm{bB}}$ & $39.13 \pm 0.21^{\mathrm{eC}}$ & $55.99 \pm 0.54^{\mathrm{cE}}$ & $49.46 \pm 0.5^{\mathrm{bD}}$ & $70.49 \pm 0.42^{\mathrm{bG}}$ & $68.63 \pm 0.52^{\mathrm{cF}}$ & $72.90 \pm 0.27^{\mathrm{cH}}$ \\
\hline \multirow[t]{3}{*}{ Poland } & $\mathrm{D}$ & $17.36 \pm 1.07^{\mathrm{cA}}$ & $35.97 \pm 0.49^{\mathrm{cC}}$ & $32.37 \pm 0.67^{\mathrm{bB}}$ & $54.23 \pm 0.46^{\mathrm{bcE}}$ & $50.68 \pm 0.99^{\mathrm{cD}}$ & $68.94 \pm 0.32^{\mathrm{aG}}$ & $66.50 \pm 0.59^{\mathrm{bF}}$ & $71.74 \pm 0.53^{\mathrm{bH}}$ \\
\hline & $\mathrm{E}$ & $19.49 \pm 0.99^{\mathrm{dA}}$ & $35.71 \pm 0.95^{\mathrm{cB}}$ & $35.09 \pm 0.53^{\mathrm{cB}}$ & $53.61 \pm 0.51^{\mathrm{bD}}$ & $49.21 \pm 0.08^{\mathrm{bC}}$ & $70.60 \pm 0.61^{\mathrm{cF}}$ & $67.30 \pm 0.53^{\mathrm{cE}}$ & $72.78 \pm 0.17^{\mathrm{aG}}$ \\
\hline & $\mathrm{F}$ & $16.68 \pm 0.77^{\mathrm{bA}}$ & $31.47 \pm 0.87^{\mathrm{aC}}$ & $30.21 \pm 0.85^{\mathrm{aB}}$ & $51.21 \pm 0.87^{\mathrm{aE}}$ & $46.34 \pm 0.46^{\mathrm{aD}}$ & $70.35 \pm 0.36^{\mathrm{bG}}$ & $64.75 \pm 0.41^{\mathrm{aF}}$ & $72.11 \pm 0.45^{\mathrm{bcH}}$ \\
\hline
\end{tabular}

\footnotetext{
${ }^{1)} \mathrm{LT}$, extracted at $25^{\circ} \mathrm{C}$; HT, extracted at $80^{\circ} \mathrm{C}$.

${ }^{2}$ Data are means $\pm \mathrm{SD}$ of triplicate experiments.

${ }^{3) \mathrm{a}-\mathrm{e}}$ Values with different superscript letters within the same column are significantly different at $\mathrm{p}<0.05$.

${ }^{4) A-D}$ Values with different superscript letters within the same row are significantly different at $\mathrm{p}<0.05$.
}

temperature, and moisture (Liu et al., 2013; Ubi et al., 2006). It also reported that the anthocyanin content of grapes increased as the amount of sunshine increased (Spayd et al., 2002).

\section{DPPH radical scavenging activity}

Table 1 shows the results of DPPH radical scavenging activity of six aronia powders grown in Korea or Poland after extraction with distilled water or $80 \%$ ethanol at $25^{\circ} \mathrm{C}$ or $80^{\circ} \mathrm{C}$. The DPPH radical scavenging activity of all of the samples increased in a concentration-dependent manner $(50-400 \mu \mathrm{g} / \mathrm{mL})$. At the same concentration, $80 \%$ ethanol extract displayed higher DPPH radical scavenging activity than water extract. In the aronia water extract, the DPPH radical scavenging activity of the sample extracted at $80^{\circ} \mathrm{C}$ was higher than that of the $25^{\circ} \mathrm{C}$ extract at the same concentration. In $80 \%$ ethanol extract, DPPH radical scavenging activity of the sample extracted at $80^{\circ} \mathrm{C}$ was higher than $25^{\circ} \mathrm{C}$. The average inhibition of the DPPH radical scavenging activity of $400 \mu \mathrm{g} / \mathrm{mL}$ aronia A extracted with water at $80^{\circ} \mathrm{C}$ was $72.01 \%$, whereas an average inhibition of $48.90 \%$ was obtained for the same sample extracted at $25^{\circ} \mathrm{C}$. The $80 \%$ ethanol extracts showed higher DPPH radical scavenging activities compared to water extraction. Sample F at $400 \mathrm{ppm}$ extracted with water, showed $39.30 \%$ DPPH radical inhibition but $70.12 \%$ inhibition in $80 \%$ ethanol extraction. Regardless of the cultivation area of aronia, the six aronia samples extracted at $80^{\circ} \mathrm{C}$ showed $70 \%$ or more DPPH radical scavenging activity at $400 \mathrm{ppm}$, and no difference in extraction solvent whether water or $80 \%$ ethanol was observed.

\section{ABTS radical scavenging activity}

Table 2 shows the results of ABTS radical scavenging activity of each of the six aronia powders grown in Korea or Poland after extraction with water or $80 \%$ ethanol at different temperatures. Similar to the DPPH radical scavenging activity, ABTS radical scavenging activity of all of the 
Table 2. ABTS radical scavenging activity of aronia in different cultivated regions

\begin{tabular}{|c|c|c|c|c|c|c|c|c|c|}
\hline \multirow{3}{*}{\multicolumn{2}{|c|}{$\begin{array}{c}\text { Cultivated } \\
\text { regions }\end{array}$}} & \multicolumn{8}{|c|}{ Concentration $(\mu \mathrm{g} / \mathrm{mL})$} \\
\hline & & \multicolumn{2}{|c|}{50} & \multicolumn{2}{|c|}{100} & \multicolumn{2}{|c|}{200} & \multicolumn{2}{|c|}{400} \\
\hline & & $\mathrm{LT}^{1)}$ & HT & $\mathrm{LT}$ & HT & $\mathrm{LT}$ & HT & $\mathrm{LT}$ & HT \\
\hline \multicolumn{10}{|c|}{ DW extract } \\
\hline \multirow[t]{3}{*}{ Korea } & A & $8.85 \pm 0.46^{2) \mathrm{e} 3) \mathrm{A} 4)}$ & $20.68 \pm 0.49^{\mathrm{eC}}$ & $12.55 \pm 1.76^{\mathrm{cB}}$ & $38.69 \pm 0.57^{\mathrm{dE}}$ & $26.54 \pm 0.44^{\mathrm{eD}}$ & $56.30 \pm 0.82^{\mathrm{dG}}$ & $43.67 \pm 0.09^{\mathrm{bF}}$ & $73.35 \pm 0.42^{\mathrm{bH}}$ \\
\hline & $\mathrm{B}$ & $5.26 \pm 0.09^{\mathrm{cA}}$ & $23.69 \pm 0.34^{\mathrm{fD}}$ & $11.24 \pm 1.14^{\mathrm{bB}}$ & $40.20 \pm 0.82^{\mathrm{fE}}$ & $20.11 \pm 0.71^{\mathrm{aC}}$ & $58.08 \pm 0.35^{\mathrm{eG}}$ & $46.69 \pm 1.16^{\mathrm{eF}}$ & $72.65 \pm 0.21^{\mathrm{aH}}$ \\
\hline & $\mathrm{C}$ & $2.09 \pm 1.38^{\mathrm{aA}}$ & $19.60 \pm 0.23^{\mathrm{dC}}$ & $10.22 \pm 0.63^{\mathrm{aB}}$ & $35.47 \pm 0.46^{\mathrm{cE}}$ & $21.88 \pm 0.92^{b D}$ & $54.11 \pm 0.16^{\mathrm{bG}}$ & $42.03 \pm 1.09^{\mathrm{aF}}$ & $73.37 \pm 0.23^{\mathrm{bH}}$ \\
\hline \multirow[t]{3}{*}{ Poland } & $\mathrm{D}$ & $7.08 \pm 1.73^{\mathrm{deA}}$ & $14.80 \pm 1.63^{\mathrm{bB}}$ & $13.97 \pm 2.66^{\mathrm{dB}}$ & $39.34 \pm 1.60^{\mathrm{eD}}$ & $25.60 \pm 0.30^{\mathrm{dC}}$ & $55.56 \pm 0.98^{\mathrm{cF}}$ & $45.68 \pm 0.19^{\mathrm{dE}}$ & $74.37 \pm 0.09^{\mathrm{cG}}$ \\
\hline & $\mathrm{E}$ & $6.37 \pm 0.36^{\mathrm{dA}}$ & $17.45 \pm 0.10^{\mathrm{cC}}$ & $15.33 \pm 0.60^{\mathrm{eB}}$ & $32.72 \pm 0.87^{\mathrm{aE}}$ & $20.90 \pm 0.09^{\mathrm{aD}}$ & $53.22 \pm 0.38^{\mathrm{aG}}$ & $44.10 \pm 0.42^{\mathrm{cF}}$ & $74.08 \pm 0.07^{\mathrm{cH}}$ \\
\hline & $\mathrm{F}$ & $4.93 \pm 1.32^{\mathrm{bA}}$ & $12.54 \pm 0.60^{\mathrm{aC}}$ & $10.50 \pm 0.16^{\mathrm{aB}}$ & $34.33 \pm 0.64^{\mathrm{bE}}$ & $22.33 \pm 1.03^{\mathrm{cD}}$ & $55.62 \pm 0.68^{\mathrm{cG}}$ & $43.49 \pm 0.48^{\mathrm{bF}}$ & $73.11 \pm 0.06^{\mathrm{bH}}$ \\
\hline \multicolumn{10}{|c|}{$80 \% \mathrm{EtOH}$ extract } \\
\hline \multirow[t]{3}{*}{ Korea } & A & $18.83 \pm 0.64^{\mathrm{dA}}$ & $25.90 \pm 0.68^{\mathrm{cB}}$ & $39.45 \pm 0.57^{\mathrm{eC}}$ & $43.33 \pm 1.06^{\mathrm{cD}}$ & $55.66 \pm 0.54^{\mathrm{dE}}$ & $59.95 \pm 0.37^{\mathrm{aF}}$ & $75.40 \pm 0.43^{\mathrm{bG}}$ & $74.75 \pm 0.37^{\mathrm{cG}}$ \\
\hline & $\mathrm{B}$ & $18.34 \pm 0.37^{\mathrm{dA}}$ & $24.43 \pm 1.27^{\mathrm{bB}}$ & $38.77 \pm 0.34^{\mathrm{dC}}$ & $40.37 \pm 0.84^{\mathrm{aD}}$ & $57.19 \pm 0.35^{\mathrm{eE}}$ & $62.32 \pm 0.73^{\mathrm{cF}}$ & $74.93 \pm 0.18^{\mathrm{aG}}$ & $74.82 \pm 0.39^{\mathrm{cG}}$ \\
\hline & $\mathrm{C}$ & $14.21 \pm 0.74^{\mathrm{bA}}$ & $24.49 \pm 0.82^{\mathrm{bB}}$ & $35.90 \pm 0.49^{\mathrm{bC}}$ & $44.42 \pm 0.16^{\mathrm{dD}}$ & $53.89 \pm 0.63^{\mathrm{cE}}$ & $64.29 \pm 0.20^{\mathrm{dF}}$ & $75.15 \pm 0.23^{\mathrm{bG}}$ & $74.92 \pm 0.64^{\mathrm{cG}}$ \\
\hline \multirow[t]{3}{*}{ Poland } & $\mathrm{D}$ & $12.82 \pm 1.68^{\mathrm{aA}}$ & $29.48 \pm 1.21^{\mathrm{dB}}$ & $37.28 \pm 0.58^{\mathrm{cC}}$ & $46.51 \pm 0.88^{\mathrm{eD}}$ & $52.73 \pm 0.93^{\mathrm{bE}}$ & $61.03 \pm 0.90^{\mathrm{bF}}$ & $74.60 \pm 0.06^{\mathrm{aH}}$ & $74.48 \pm 0.21^{\mathrm{bG}}$ \\
\hline & $\mathrm{E}$ & $16.33 \pm 1.01^{\mathrm{cA}}$ & $24.85 \pm 0.46^{\mathrm{bB}}$ & $38.54 \pm 2.18^{\mathrm{dC}}$ & $48.10 \pm 0.56^{\mathrm{fD}}$ & $57.79 \pm 0.52^{\mathrm{eE}}$ & $69.08 \pm 0.34^{\mathrm{fF}}$ & $74.93 \pm 0.33^{\mathrm{aG}}$ & $74.05 \pm 0.36^{\mathrm{bFG}}$ \\
\hline & $\mathrm{F}$ & $14.66 \pm 1.74^{\mathrm{bA}}$ & $20.06 \pm 0.61^{\mathrm{aB}}$ & $34.51 \pm 1.12^{\mathrm{aC}}$ & $42.16 \pm 1.14^{\mathrm{bD}}$ & $51.10 \pm 0.40^{\mathrm{aE}}$ & $68.46 \pm 0.25^{\mathrm{eF}}$ & $75.41 \pm 0.41^{\mathrm{bG}}$ & $75.31 \pm 0.26^{\mathrm{aFG}}$ \\
\hline
\end{tabular}

${ }^{1)} \mathrm{LT}$, extracted at $25^{\circ} \mathrm{C}$; HT, extracted at $80^{\circ} \mathrm{C}$.

${ }^{2}$ Data are means \pm SD of triplicate experiments.

${ }^{3) \mathrm{a}-\mathrm{e}}$ Values with different superscript letters within the same column are significantly different at $\mathrm{p}<0.05$.

${ }^{4) A-D}$ Values with different superscript letters within the same row are significantly different at $\mathrm{p}<0.05$.

samples increased in a concentration-dependent manner $(50-400 \mu \mathrm{g} / \mathrm{mL})$. At the same concentration, $80 \%$ ethanol extract showed higher ABTS radical scavenging activity than water extract. In the aronia water extract, the ABTS radical scavenging activity of the sample extracted at $80^{\circ} \mathrm{C}$ was higher than the $25^{\circ} \mathrm{C}$ extract at the same concentration. In $80 \%$ ethanol extract, up to $200 \mathrm{ppm}$ ABTS radical scavenging activity of the sample extracted at $80^{\circ} \mathrm{C}$ was higher than $25^{\circ} \mathrm{C}$, but at $400 \mathrm{ppm}$ the ABTS radical scavenging activity was not significantly changed with temperature.

The average inhibition of the ABTS radical scavenging activity of aronia A $(400 \mu \mathrm{g} / \mathrm{mL})$ extracted with water at 8 $0^{\circ} \mathrm{C}$ was $73.35 \%$, whereas an average inhibition of $43.67 \%$ was obtained for the same sample extracted at $25^{\circ} \mathrm{C}$. Aronia extracted with $80 \%$ ethanol at $50-200 \mu \mathrm{g} / \mathrm{mL}$ showed higher ABTS radical scavenging activity as compared to water extraction. However, in $80 \%$ ethanol extract of aronia (400 $\mu \mathrm{g} / \mathrm{mL}$ ), the ABTS radical scavenging activity showed no difference with temperature. That is, the ABTS radical scavenging activity of the $80 \%$ ethanol extracted at $25^{\circ} \mathrm{C}$ or $80^{\circ} \mathrm{C}$ showed almost the same degree. At $400 \mu \mathrm{g} / \mathrm{mL}$ concentration, sample $\mathrm{F}$ extracted with water showed $75.41 \%$ ABTS radical inhibition, but $75.31 \%$ inhibition in $80 \%$ ethanol extraction. Regardless of the cultivation area of aronia, the six aronia samples showed almost the same ABTS radical scavenging activity of $70 \%$ or more at 400 $\mu \mathrm{g} / \mathrm{mL}$, and no difference in extraction solvent was observed.

\section{Reducing power activity}

Table 3 shows the reducing power based on the extraction solvent and the extraction temperature of aronia powder cultivated in Korea or Poland. The higher the absorbance measured at $700 \mathrm{~nm}$, the higher the reducing power. Similar to DPPH or ABTS radical scavenging activity, the reducing power was higher in the $80^{\circ} \mathrm{C}$ extract than in the $25^{\circ} \mathrm{C}$ extract, and the reducing power was higher in the $80 \%$ ethanol extract than in the water extract. In case of $50 \mu \mathrm{g} / \mathrm{mL}$ 
Table 3. Reducing power activity of aronia in different cultivated regions

\begin{tabular}{|c|c|c|c|c|c|c|c|c|c|}
\hline \multirow{3}{*}{\multicolumn{2}{|c|}{$\begin{array}{c}\text { Cultivated } \\
\text { regions }\end{array}$}} & \multicolumn{8}{|c|}{ Concentration $(\mu \mathrm{g} / \mathrm{mL})$} \\
\hline & & \multicolumn{2}{|c|}{50} & \multicolumn{2}{|c|}{100} & \multicolumn{2}{|c|}{200} & \multicolumn{2}{|c|}{400} \\
\hline & & $\mathrm{LT}^{1)}$ & HT & $\mathrm{LT}$ & HT & $\mathrm{LT}$ & HT & $\mathrm{LT}$ & HT \\
\hline \multicolumn{10}{|c|}{ DW extract } \\
\hline \multirow[t]{3}{*}{ Korea } & A & $\begin{array}{c}0.0736 \\
\pm 0.0004^{2) \mathrm{b} 33 \mathrm{~A} 4)}\end{array}$ & $\begin{array}{c}0.1065 \\
\pm 0.0001^{\mathrm{bC}}\end{array}$ & $\begin{array}{c}0.0873 \\
\pm 0.0005^{\mathrm{cB}}\end{array}$ & $\begin{array}{c}0.1421 \\
\pm 0.0013^{\mathrm{dE}}\end{array}$ & $\begin{array}{c}0.1235 \\
\pm 0.0009^{\mathrm{cD}}\end{array}$ & $\begin{array}{c}0.2122 \\
\pm 0.0016^{\mathrm{CG}}\end{array}$ & $\begin{array}{c}0.1743 \\
\pm 0.0014^{\mathrm{cF}}\end{array}$ & $\begin{array}{c}0.3895 \\
\pm 0.0007^{\mathrm{fH}}\end{array}$ \\
\hline & B & $\begin{array}{c}0.0611 \\
\pm 0.0002^{\mathrm{aA}}\end{array}$ & $\begin{array}{c}0.1045 \\
\pm 0.0008^{\mathrm{bC}}\end{array}$ & $\begin{array}{c}0.0677 \\
\pm 0.0007^{\mathrm{aA}}\end{array}$ & $\begin{array}{c}0.1524 \\
\pm 0.0011^{\mathrm{eE}}\end{array}$ & $\begin{array}{c}0.0832 \\
\pm 0.0004^{\mathrm{aB}}\end{array}$ & $\begin{array}{c}0.2114 \\
\pm 0.0014^{\mathrm{cF}}\end{array}$ & $\begin{array}{c}0.1180 \\
\pm 0.0005^{\mathrm{aD}}\end{array}$ & $\begin{aligned} & 0.3476 \\
\pm & 0.0048^{\mathrm{cG}}\end{aligned}$ \\
\hline & $\mathrm{C}$ & $\begin{array}{c}0.0606 \\
\pm 0.0012^{\mathrm{aA}}\end{array}$ & $\begin{array}{c}0.1004 \\
\pm 0.0014^{\mathrm{bD}}\end{array}$ & $\begin{array}{c}0.0708 \\
\pm 0.0008^{\mathrm{bB}}\end{array}$ & $\begin{array}{c}0.1327 \\
\pm 0.0004^{\mathrm{cE}}\end{array}$ & $\begin{array}{c}0.0955 \\
\pm 0.0006^{\mathrm{bC}}\end{array}$ & $\begin{array}{c}0.2115 \\
\pm 0.0006^{\mathrm{cF}}\end{array}$ & $\begin{array}{c}0.1357 \\
\pm 0.0003^{\mathrm{bE}}\end{array}$ & $\begin{aligned} & 0.3681 \\
& \pm 0.0054^{\mathrm{eG}}\end{aligned}$ \\
\hline \multirow[t]{3}{*}{ Poland } & $\mathrm{D}$ & $\begin{array}{c}0.0793 \\
\pm 0.0005^{\mathrm{bA}}\end{array}$ & $\begin{array}{c}0.0923 \\
\pm 0.0013^{\mathrm{aB}}\end{array}$ & $\begin{array}{c}0.0981 \\
\pm 0.0005^{\mathrm{dB}}\end{array}$ & $\begin{array}{c}0.1296 \\
\pm 0.0016^{\mathrm{bC}}\end{array}$ & $\begin{array}{c}0.1345 \\
\pm 0.0005^{\mathrm{dD}}\end{array}$ & $\begin{array}{c}0.1916 \\
\pm 0.0011^{\mathrm{bE}}\end{array}$ & $\begin{array}{c}0.2044 \\
\pm 0.0008^{\mathrm{eF}}\end{array}$ & $\begin{array}{c}0.3149 \\
\pm 0.0014^{\mathrm{bG}}\end{array}$ \\
\hline & $\mathrm{E}$ & $\begin{array}{c}0.0821 \\
\pm 0.0002^{\mathrm{cA}}\end{array}$ & $\begin{array}{c}0.0997 \\
\pm 0.0001^{\mathrm{aB}}\end{array}$ & $\begin{array}{c}0.1007 \\
\pm 0.0010^{\text {eC }}\end{array}$ & $\begin{array}{c}0.1394 \\
\pm 0.0009^{\mathrm{cD}}\end{array}$ & $\begin{array}{c}0.1404 \\
\pm 0.0006^{\mathrm{eE}}\end{array}$ & $\begin{array}{c}0.2163 \\
\pm 0.0009^{\mathrm{cF}}\end{array}$ & $\begin{array}{c}0.2141 \\
\pm 0.0022^{\mathrm{eF}}\end{array}$ & $\begin{array}{c}0.3574 \\
\pm 0.0031^{\mathrm{dG}}\end{array}$ \\
\hline & $\mathrm{F}$ & $\begin{array}{c}0.0770 \\
\pm 0.0006^{\mathrm{bA}}\end{array}$ & $\begin{array}{c}0.0908 \\
\pm 0.0009^{\mathrm{aB}}\end{array}$ & $\begin{array}{c}0.0953 \\
\pm 0.0007^{\mathrm{dB}}\end{array}$ & $\begin{array}{c}0.1174 \\
\pm 0.0014^{\mathrm{aC}}\end{array}$ & $\begin{array}{c}0.1246 \\
\pm 0.0003^{\mathrm{cD}}\end{array}$ & $\begin{array}{c}0.1746 \\
\pm 0.0004^{\mathrm{aE}}\end{array}$ & $\begin{array}{c}0.1852 \\
\pm 0.0005^{\mathrm{dF}}\end{array}$ & $\begin{array}{c}0.2747 \\
\pm 0.0022^{\mathrm{aG}}\end{array}$ \\
\hline \multicolumn{10}{|c|}{$80 \%$ EtOH extract } \\
\hline \multirow[t]{3}{*}{ Korea } & A & $\begin{array}{c}0.0962 \\
\pm 0.0003^{\mathrm{bA}}\end{array}$ & $\begin{array}{c}0.1008 \\
\pm 0.0004^{\mathrm{bB}}\end{array}$ & $\begin{array}{c}0.1504 \\
\pm 0.0003^{\mathrm{CC}}\end{array}$ & $\begin{array}{c}0.1804 \\
\pm 0.0006^{\mathrm{CD}}\end{array}$ & $\begin{array}{c}0.2373 \\
\pm 0.0022^{\mathrm{dE}}\end{array}$ & $\begin{array}{c}0.2459 \\
\pm 0.0008^{\mathrm{dF}}\end{array}$ & $\begin{array}{c}0.3149 \\
\pm 0.0127^{\mathrm{aG}}\end{array}$ & $\begin{array}{c}0.4359 \\
\pm 0.0029^{\mathrm{bH}}\end{array}$ \\
\hline & B & $\begin{array}{c}0.0940 \\
\pm 0.0009^{\mathrm{aA}}\end{array}$ & $\begin{array}{c}0.1093 \\
\pm 0.0013^{\mathrm{aB}}\end{array}$ & $\begin{array}{c}0.1336 \\
\pm 0.0002^{\mathrm{aC}}\end{array}$ & $\begin{array}{c}0.1690 \\
\pm 0.0010^{\mathrm{aD}}\end{array}$ & $\begin{array}{c}0.2253 \\
\pm 0.0018^{\mathrm{cE}}\end{array}$ & $\begin{array}{c}0.2620 \\
\pm 0.0011^{\mathrm{eF}}\end{array}$ & $\begin{array}{c}0.3552 \\
\pm 0.0049^{\mathrm{cG}}\end{array}$ & $\begin{array}{c}0.4786 \\
\pm 0.0044^{\mathrm{cH}}\end{array}$ \\
\hline & $\mathrm{C}$ & $\begin{array}{c}0.0972 \\
\pm 0.0003^{\mathrm{cA}}\end{array}$ & $\begin{array}{c}0.1063 \\
\pm 0.0003^{\mathrm{bB}}\end{array}$ & $\begin{array}{c}0.1349 \\
\pm 0.0012^{\mathrm{aC}}\end{array}$ & $\begin{array}{c}0.1491 \\
\pm 0.0007^{\mathrm{bD}}\end{array}$ & $\begin{array}{c}0.2029 \\
\pm 0.0005^{\mathrm{aE}}\end{array}$ & $\begin{array}{c}0.2391 \\
\pm 0.0005^{\mathrm{cF}}\end{array}$ & $\begin{array}{c}0.3525 \\
\pm 0.0019^{\mathrm{cG}}\end{array}$ & $\begin{array}{c}0.4969 \\
\pm 0.0023^{\mathrm{dH}}\end{array}$ \\
\hline \multirow[t]{3}{*}{ Poland } & $\mathrm{D}$ & $\begin{array}{c}0.0975 \\
\pm 0.0015^{\mathrm{cA}}\end{array}$ & $\begin{array}{c}0.1043 \\
\pm 0.0012^{\mathrm{bB}}\end{array}$ & $\begin{array}{c}0.1321 \\
\pm 0.0011^{\mathrm{aC}}\end{array}$ & $\begin{array}{c}0.1484 \\
\pm 0.0002^{\mathrm{bD}}\end{array}$ & $\begin{array}{c}0.2026 \\
\pm 0.0005^{\mathrm{aE}}\end{array}$ & $\begin{array}{c}0.2138 \\
\pm 0.0019^{\mathrm{aF}}\end{array}$ & $\begin{array}{c}0.3356 \\
\pm 0.0020^{\mathrm{bG}}\end{array}$ & $\begin{array}{c}0.4724 \\
\pm 0.0002^{\mathrm{cH}}\end{array}$ \\
\hline & $\mathrm{E}$ & $\begin{array}{c}0.0964 \\
\pm 0.0006^{\mathrm{bA}}\end{array}$ & $\begin{array}{c}0.1081 \\
\pm 0.0005^{\text {bB }}\end{array}$ & $\begin{array}{c}0.1489 \\
\pm 0.0002^{\mathrm{bC}}\end{array}$ & $\begin{array}{c}0.1573 \\
\pm 0.0003^{\mathrm{cD}}\end{array}$ & $\begin{array}{c}0.2190 \\
\pm 0.0022^{\mathrm{bE}}\end{array}$ & $\begin{array}{c}0.2434 \\
\pm 0.0008^{\mathrm{dF}}\end{array}$ & $\begin{array}{c}0.3113 \\
\pm 0.0009^{\mathrm{aG}}\end{array}$ & $\begin{array}{c}0.4329 \\
\pm 0.0026^{\mathrm{bH}}\end{array}$ \\
\hline & $\mathrm{F}$ & $\begin{array}{c}0.0902 \\
\pm 0.0008^{\mathrm{aA}}\end{array}$ & $\begin{array}{c}0.0958 \\
\pm 0.0004^{\mathrm{aB}}\end{array}$ & $\begin{array}{c}0.1431 \\
\pm 0.0001^{\mathrm{bC}}\end{array}$ & $\begin{array}{c}0.1513 \\
\pm 0.0010^{\mathrm{cD}}\end{array}$ & $\begin{array}{c}0.2002 \\
\pm 0.0015^{\mathrm{aE}}\end{array}$ & $\begin{array}{c}0.2204 \\
\pm 0.0006^{\mathrm{bF}}\end{array}$ & $\begin{array}{c}0.3639 \\
\pm 0.0012^{\mathrm{dG}}\end{array}$ & $\begin{array}{c}0.4224 \\
\pm 0.0002^{\mathrm{aH}}\end{array}$ \\
\hline
\end{tabular}

${ }^{1)} \mathrm{LT}$, extracted at $25^{\circ} \mathrm{C}$; HT, extracted at $80^{\circ} \mathrm{C}$.

${ }^{2)}$ Data are mean $\pm \mathrm{SD}$ of triplicate experiments.

3)a-e Values with different superscript letters within the same column are significantly different at $\mathrm{p}<0.05$.

${ }^{4) A-D}$ Values with different superscript letters within the same row are significantly different at $\mathrm{p}<0.05$.

of aronia extract, the absorbance of sample $\mathrm{C}$ extracted at $25^{\circ} \mathrm{C}$ with distilled water was the lowest at 0.0606 , and the absorbance of Sample E was the highest at 0.0821. When the same sample was extracted at $80^{\circ} \mathrm{C}$, the absorbance was higher than that of the $25^{\circ} \mathrm{C}$ extract. Reducing power displayed a pattern increasing with concentration. That is, in case of sample A, grown in Korea and extracted with $80 \%$ ethanol at $80^{\circ} \mathrm{C}$, the reducing power was increased by 1.78 , 2.44 , and 4.32 times at concentrations of 100, 200, and 400 $\mu \mathrm{g} / \mathrm{mL}$ as compared to $50 \mu \mathrm{g} / \mathrm{mL}$. The reducing power showed a pattern increasing with concentration. In other words, the sample E grown in Poland extracted with $80 \%$ ethanol at $80^{\circ} \mathrm{C}$ increased the reducing power by $1.46,2.25$, and 4.00 times at concentrations of 100,200 , and $400 \mu \mathrm{g} / \mathrm{mL}$ compared to $50 \mu \mathrm{g} / \mathrm{mL}$.

Similar to the results of this study, the total polyphenol and flavonoid content of aronia in the study of Hong and Hong (2015) in water and 70\% ethanol extract was much higher in $70 \%$ ethanol extract than water extract. DPPH and ABTS radical scavenging activities were increased based on the concentration in water and $70 \%$ ethanol extract, and the functional content and antioxidant activity of aronia were 
$70 \%$ more effective than water extraction. It was confirmed that the antioxidative activity of Korea aronia and Polish aronia was similar or slightly higher than that of Poland.

In conclusion, the content of bioactive substances and antioxidant activity of three types of aronia grown in three Korea regions and three types of powdered aronia imported from Poland were compared. The total polyphenol content was higher in $80 \%$ ethanol extracts than in water extracts, in the 6 samples from Korea and Poland. The total polyphenol content of the sample extracted at $25^{\circ} \mathrm{C}$ was higher than that of $80^{\circ} \mathrm{C}$. The total flavonoid content according to the solvent and extraction temperature was higher in order: $25^{\circ} \mathrm{C}$ distilled water $<80^{\circ} \mathrm{C}$, distilled water $<80^{\circ} \mathrm{C}, 80 \%$ ethanol $<25^{\circ} \mathrm{C}, 80 \%$ ethanol extract. HPLC analysis identified four anthocyanin substances i.e. cyanidin-3-O-galactoside, cyanidin-3-O-glucoside, cyanidin-3$O$-arabinoside, and cyanidin-3-O-xyloside. The anthocyanin content in the other five samples showed a similar tendency except for sample E, which had the highest anthocyanin content in the $80 \%$ ethanol extract. The $80 \%$ ethanol extract showed higher antioxidant activity than water extract and in the aronia water extract, the antioxidant activity of the sample extracted at $80^{\circ} \mathrm{C}$ was higher than that of the $25^{\circ} \mathrm{C}$ extract at the same concentration. It was confirmed that the antioxidative activity of Korea aronia and Polish aronia was similar or slightly higher in the Korea aronia.

\section{Conflict of interests}

The authors declare no potential conflict of interest.

\section{ORCID}

Eun-Sun Hwang https://orcid.org/0000-0001-6920-3330

You Ji Lee https://orcid.org/0000-0001-8284-2305

\section{References}

Bolling BW, Taheri R, Pei R, Kranz S, Yu M, Duracher SN, Brand MH. Harvest date affects aronia juice polyphenols, sugars, and antioxidant activity, but not anthocyanin stability. Food Chem, 187, 189-196 (2015)

Cheung LM, Cheung PCK, Ooi VEC. Antioxidant activity and total phenolics of edible mushroom extracts. Food Chem, 81, 249-255 (2003)
Domarew CA, Holt RR, Goodman-Snitkoff G. A study of Russian phytomedicine and commonly used herbal remedies. J Herb Pharmacother, 2, 31-48 (2002)

Girones-Vilaplana A, Valentao P, Andrade PB, Ferreres F, Moreno DA, Garcia-Viguera C. Phytochemical profile of a blend of black chokeberry and lemon juice with cholinesterase inhibitory effect and antioxidant potential. Food Chem, 134, 2090-2096 (2012)

Hellstrom JK, Shikov AN, Makarova MN, Pihlanto AM, Pozharitskaya ON, Ryhanen EL, Kivijarvi P, Makarov VG, Mattila PH. Blood pressure-lowering properties of chokeberry (Aronia mitchurinii, var. Viking). J Funct Foods, 2, 163-169 (2010)

Hong M, Hong C. Functional components and antioxidant activities of extracts of aronia (Aronia melanocarpa). Korean Food Serv Management Res, 11, 81-91 (2015)

Hwang ES, Thi ND. Antioxidant contents and antioxidant activities of hot-water extracts of aronia (Aronia melancocarpa) with different drying methods. Korean $\mathrm{J}$ Food Sci Technol, 46, 303-308 (2014)

Hwang ES, Thi ND. Effects of different growing regions on quality characteristics, bioactive compound contents, and antioxidant activity of aronia (Aronia melanocarpa) in Korea. Prev Nutr Food Sci, 21, 255-262 (2016)

Hwang YR, Hwang ES. Quality characteristics and antioxidant activity of Sulgidduk prepared by addition of aronia powder (Aronia melanocarpa). Korean J Food Sci Technol, 47, 452-459 (2015)

Jakobek L, Drenjancevic M, Jukic V, Seruga M. Phenolic acids, flavonols, anthocyanins and antiradical activity of "Nero", "Viking", "Galicianka" and wild chokeberries. Sci Hortic, 147, 56-63 (2012)

Jeon JA, Choi JS, Jung EH, Kim CW, Bae EJ, Jeong ST. The quality characteristics of aronia by cultivation region. Korean J Food Preserv, 25, 804-810 (2018)

Jeong YJ, Lee AR, Park JH, Kim Y, Kwon Y, Hong EY, Han NS, Eom HJ. Nutritional compositions and physicochemical properties of two domestic aronia $(A$. melanocarpa) varieties. Korean J Food Nutr, 29, 283-289 (2016)

Koponen JM, Happonen AM, Mattila PH, Torronen AR. Contents of anthocyanins and ellagitannins in selected foods consumed in Finland. J Agric Food Chem, 55, 1612-1619 (2007) 
Lee JH, Choi JE. Quality characteristics and antioxidant activities of cookies supplemented with aronia powder. J Korean Soc Food Sci Nutr, 45, 1071-1076 (2016)

Liu Y, Che F, Wang L, Meng R, Zhang X, Zhao Z. Fruit coloration and anthocyanin biosynthesis after bag removal in non-red and red apples (Malus $\times$ domestica Borkh.). Molecules, 18, 1549-1563 (2013)

Nguyen L, Hwang ES. Quality characteristics and antioxidant activity of yogurt supplemented with aronia (Aronia melanocarpa) juice. Prev Nutr Food Sci, 21, 330-337 (2016)

Oszmianski J, Wojdylo A. Aronia melanocarpa phenolics and their antioxidant activity. Eur Food Res Technol, 221, 809-813 (2005)

Oyaizu M. Studies on product of browning reaction: antioxidative activities of products of browning prepared from glucoseamine. Jap J Nutr, 44, 307-315 (1986)

Re R, Pellegrini N, Proteggente A, Pannala A, Yang M, Rice-Evans C. Antioxidant activity applying an improved ABTS radical cation decolorization assay. Free Radical Biol Med, 26, 1231-1237 (1999)

Slimestad R, Torskangerpoll K, Nateland HS, Johannessen T, Giske NH. Flavonoids from black chokeberries, Aronia melanocarpa. J Food Compos Anal, 18, 61-68 (2005)
Spayd SE, Tarara JM, Mee DL, Ferguson JC. Separation of sunlight and temperature effects on the composition of Vitis vinifera cv. Merlot berries. Am J Enol Vitic, 53, 171-182 (2002)

Tolic1 M, Jurcevic IL, Krbavcic IP, Markovic K, Vahcic N. Phenolic content, antioxidant capacity and quality of chokeberry (Aronia melanocarpa) products. Food Technol Biotechnol, 53, 171-179 (2015)

Takashi T. The effect of environmental temperatures on fruit maturing. J Kor Soc Hort Sci, 24, 276-288 (1983)

Ubi BE, Honda C, Bessho H, Kondo S, Wada M, Kobayashi $\mathrm{S}$, Moriguchi T. Expression analysis of anthocyanin biosynthetic genes in apple skin: Effect of UV-B and temperature. Plant Sci, 170, 571-578 (2006)

Waterhouse AL. Determination of total phenolics. In: Current Protocols in Food Analytical Chemistry, Wrolstad RE (Editor), John Wiley and Sons Inc., New York, NY, USA, p. I1.1.1-1.1.8 (2002)

Woisky R, Salatino A. Analysis of propolis: Some parameters and procedures for chemical quality control. J Apicul Res, 38, 99-105 (1998)

Wu X, Gu L, Prior RL, McKay S. Characterization of anthocyanins and proanthocyanidins in some cultivars of Ribes, aronia, and sambucus and their antioxidant capacity. J Agric Food Chem, 52, $7846-7856$ (2004) 